\title{
REVIEW
}

\section{Pheochromocytomas and paragangliomas in von Hippel-Lindau disease: not a needle in a haystack}

\author{
João Castro-Teles ${ }^{1}$, Bernardo Sousa-Pinto ${ }^{2,3}$, Sandra Rebelo ${ }^{1,4,5}$ and Duarte Pignatelli ${ }^{1,4,6,7}$ \\ 'Department of Biomedicine, Faculty of Medicine of the University of Porto, Porto, Portugal \\ ${ }^{2}$ MEDCIDS, Department of Community Medicine, Information and Health Decision Sciences, Faculty of Medicine, University of Porto, Porto, Portugal \\ ${ }^{3}$ CINTESIS, Center for Health Technology and Services Research, University of Porto, Porto, Portugal \\ ${ }^{4}$ Instituto de Investigação e Inovação em Saúde (i3S), Universidade do Porto, Porto, Portugal \\ ${ }^{5}$ Department of Clinical Pathology, Centro Hospitalar Universitário de São João (CHUSJ), Porto, Portugal \\ ${ }^{6}$ Institute of Molecular Pathology and Immunology of the University of Porto (IPATIMUP), Porto, Portugal \\ ${ }^{7}$ Department of Endocrinology, Centro Hospitalar Universitário de São João (CHUSJ), Porto, Portugal
}

Correspondence should be addressed to D Pignatelli: dpignatelli@ipatimup.pt

\begin{abstract}
Objective: Pheochromocytomas are a hallmark feature of von Hippel-Lindau disease $(\mathrm{vHL})$. To our knowledge, this is the first systematic review with meta-analysis evaluating the frequency of pheochromocytomas and/or paragangliomas (PPGLs) in patients with $\mathrm{vHL}$, as well as among patients with different $\mathrm{vHL}$ subtypes.

Design: Systematic review with meta-analysis.

Methods: We searched on MEDLINE, Scopus, and Web of Science. We included primary studies assessing participants with $\mathrm{VHL}$ and reporting on the frequency of PPGL. We performed random-effects meta-analysis to quantitatively assess the frequency of PPGL, followed by meta-regression and subgroup analysis. Risk of bias analysis was performed to assess primary studies' methodological quality.

Results: We included 80 primary studies. In 4263 patients with $\mathrm{vHL}$, the pooled frequency of PPGL was $19.4 \%\left(95 \% \mathrm{Cl}=15.9-23.6 \%, l^{2}=86.1 \%\right)$. The frequency increased to $60.0 \%$ in patients with $\mathrm{vHL}$ type $2\left(95 \% \mathrm{Cl}=53.4-66.3 \%, I^{2}=54.6 \%\right)$ and was determined to be of $58.2 \%$ in patients with vHL type $2 \mathrm{~A}\left(95 \% \mathrm{Cl}=49.7-66.3 \%, \mathrm{I}^{2}=36.2 \%\right)$, compared to $49.8 \%$ in vHL type $2 \mathrm{~B}\left(95 \% \mathrm{Cl}=39.9-59.7 \%, I^{2}=42.7 \%\right)$, and $84.1 \%$ in vHL type $2 \mathrm{C}$ $\left(95 \% \mathrm{Cl}=75.1-93.1 \%, l^{2}=0 \%\right)$. In meta-regression analysis, more recent studies were associated with a higher frequency of PPGL. All studies had at least one internal validity item classified as 'high risk of bias,' with $13 \%$ studies having low risk of bias in all external validity items.
\end{abstract}

Conclusions: PPGLs are a common manifestation of VHL. Despite methodological limitations and differences across primary studies, our results point to the importance of PPGL screening in patients with vHL.

\section{Introduction}

Von Hippel-Lindau disease (vHL) is a rare hereditary autosomal dominant disorder resulting from the presence of pathogenic variants on the VHL gene (1), with a point prevalence estimated (as per the first nationwide study on the subject) at 1:46,900 individuals, a birth incidence at $1: 27,300$ live births, and an overall penetrance of $87 \%$ at 60 years of age (2). Carriers of disease-causing VHL germline variants are at an increased risk of developing benign 
and malignant neoplasms, such as hemangioblastomas and pheochromocytomas. Pheochromocytomas and paragangliomas (PPGLs), arising either through germline VHL mutations in a syndromic setting or via somatic VHL mutations sporadically, associate with the pseudo-hypoxic mRNA expressional cluster 1 in which an increased risk of metastatic events is seen compared to tumors arising within the kinase-associated cluster 2, containing more biologically indolent tumors $(3,4)$. Pheochromocytomas are more frequently diagnosed during the third decade of life although they may also be the presenting feature in the pediatric setting $(2,5)$. Pheochromocytoma is such a hallmark feature of vHL that its absence or presence, respectively, underlies the phenotypic classification in type 1 , which is typically associated with protein-truncating mutations, or vHL type 2 , which mainly associates with missense mutations (6). vHL type 2 is further subdivided into types $2 \mathrm{~A}$ (low risk of renal cell carcinoma), 2B (high risk of renal cell carcinoma), and 2C (only pheochromocytoma without other vHL manifestations) $(6,7)$. In the clinical setting, even though surveillanceprotocolsaregenerallysimilarforallvHL patients, this classification is particularly useful for appropriate intrafamilial risk management and prognosis assessment since the risk of developing pheochromocytomas in vHLaffected family members increases once the history of pheochromocytoma in the family is reported and the family is considered of type $2 \mathrm{vHL}$.

An Italian nationwide prospective study assessing individuals with vHL found that $30 \%$ of participants developed pheochromocytoma, resulting in a cumulative incidence of adrenal disability of $11 \%$ after surgery, requiring adrenal substitutive therapy. Those patients underwent surgery for pheochromocytoma at a mean age of 27 years, similar to those who underwent surgery for hemangioblastoma (28 years) and earlier than those who underwent surgery for renal and pancreatic neoplasms (37 and 35 years old, respectively) (8). Therefore, international clinical practice guidelines support early detection of pheochromocytomas in vHL patients, as it may allow for more advanced surgical techniques such as cortical-sparing and laparoscopic procedures - to be performed, resulting in lower risk of recurrence and maintenance of corticosteroid independence $(9,10)$.

However, notwithstanding the burden of pheochromocytoma in vHL and despite the benefits of early and lifetime screening for this neoplasm in patients with vHL (11), the prevalence of pheochromocytoma in patients with vHL has not been systematically ascertained. Several studies have reported the frequency of pheochromocytoma in cohorts of patients with vHL, but with relevant disparities, mirroring their differences in study design, methodological quality, and sample size. Thus, this systematic review aims to determine the frequency of pheochromocytoma and/or PPGL in patients with vHL (and in patients with each vHL subtype), as well as to identify variables potentially explaining across-study differences on the frequency of PPGL.

\section{Materials and methods}

This study corresponds to a systematic review with meta-analysis following the Preferred Reporting Items for Systematic Reviews and Meta-Analyses (PRISMA) statement (12).

\section{Eligibility criteria}

To determine the frequency of PPGL in vHL, we included cohorts of patients with vHL - either fulfilling clinical diagnostic criteria of vHL or carrying VHL germline pathogenic mutations - which have reported data on the number of patients/mutation carriers with PPGL. In order to determine the frequency of PPGL in each vHL subtype, we also included family reports that have reported data on the number of patients/mutation carriers with $\mathrm{vHL}$ of each subtype with PPGL. To assess the frequency of PPGL in vHL type $2 \mathrm{C}$, we included only studies that have performed molecular screening of asymptomatic family members (once PPGL is the only phenotypic feature in vHL type $2 \mathrm{C}$, all patients clinically diagnosed with vHL type $2 \mathrm{C}$ have a history of PPGL; therefore, we included only primary studies that performed genetic screening of asymptomatic family members so that we were able to assess the frequency of PPGL in all family members with the vHL type 2C mutation). We excluded case-control studies, case series of pheochromocytoma/PPGL patients, and studies in which patient selection was based on specific phenotypic manifestations (e.g. case series of vHL patients with hemangioblastomas).

\section{Search strategy and study selection}

Studies were identified in February 2020 through a search conducted on three electronic bibliographic databases (MEDLINE/PubMed, Web of Science, and Scopus) using the queries displayed in Supplementary Table 1 (see section on supplementary materials given at the end of this article). No language or date restrictions were applied.

Following duplicate removal, screening of the titles and abstracts was independently conducted by two researchers.

This work is licensed under a Creative Commons Attribution-NonCommercial-NoDerivatives 4.0 International License.ifica com at $04 / 26 / 2023$ 10:18:13AM 
The full texts of selected studies were then independently read by two researchers, whodecided on their final inclusion. For publications in which complete or partial overlap of participants with other studies occurred, we presented only information from the publication with more participants, eventually complementing with relevant information from other publications on covariates of interest.

\section{Data extraction}

Two researchers independently extracted relevant data from included studies regarding their year of publication, country, sampling method, method of vHL diagnosis (clinical and/or molecular), number of vHL patients/mutation carriers, participants' gender and age distributions, number of asymptomatic carriers of $V H L$ pathogenic mutations, number of patients with positive family history of vHL disease, and number of patients with PPGL (including the number of patients with bilateral adrenal presentation). Our outcome variable consisted of the number of patients with PPGL (instead of the number of patients with pheochromocytoma), as many studies did not differentiate between adrenal pheochromocytoma and PPGL/extra-adrenal pheochromocytoma (13). Nevertheless, we also collected separate data regarding the frequency of pheochromocytoma and PPGL whenever these entities were adequately distinguished. We also retrieved information concerning the number of vHL patients/mutation carriers with each vHL phenotypic subtype (vHL type $2 \mathrm{~A}$, vHL type $2 \mathrm{~B}$, vHL type 2C) and the number of patients with each vHL subtype who had PPGL.

For data collection, we used a purpose-built form developed after a pilot version. Authors were contacted to provide relevant missing information. In cases of disagreement regarding study selection or data extraction, a consensus was achieved.

\section{Quality assessment}

Study quality wasindependently assessed by two researchers according to an adapted version of the Hoy et al. judgments on the risk of bias of prevalence studies (14). Three risk of bias items were excluded as they did not adequately apply to our study, namely that regarding data provenance (directly from subjects vs from a proxy) on account of the type of data we were retrieving, that concerning reliability and validity of the study instrument used to measure the parameter of interest, and that regarding the suitability of the length of the shortest prevalence period (as we were not assessing a specific prevalence period).

\section{Quantitative synthesis}

We performed random-effects meta-analyses to estimate the pooled frequency of PPGL among patients with vHL, as well as among patients with each vHL subtype. In addition, we computed the meta-analytical frequency of patients with PPGL who presented with bilateral neoplasms or who were of the male sex. To account for possible bias resulting from studies assessing small samples (with the possibility of most patients being from a small number of families), we performed sensitivity analyses restricted to studies with more than 25 participants.

Meta-analysis was performed based on the restricted maximum likelihood method, using logit-transformed proportions. Pooled results were back-transformed to their original scale to facilitate their interpretation. Heterogeneity was assessed using the $I^{2}$ statistic and Cochran Q test $P$ value - an $I^{2}>50 \%$ and a $P$ value $<0.10$ were considered to represent substantial heterogeneity. In the presence of substantial heterogeneity, we performed meta-regression and subgroup analyses in order to identify variables possibly explaining across-study differences. Covariates tested include the publication year, sample size, percentage of male participants, mean participants' age, region (Europe, America, and Asia and Pacific), sampling method (consecutive, convenience, or not specified), and vHL diagnosis method (clinical criteria only or including genetic testing/not specified). All statistical analyses were performed using metafor package of software $\mathrm{R}$ (version 4.0.0.).

\section{Results}

\section{Search results}

Our search yielded 2557 publications, of which 906 were duplicates. One thousand four hundred ten studies were excluded on the basis of application of eligibility criteria (Fig. 1). Fifty-five records were excluded due to partial or complete overlap of participants with included publications. We could not obtain the full text of 13 publications despite contacting corresponding authors (Supplementary Table 2). Seven of these articles were published in a language other than English, and six were published before 2000 .

A total of 80 studies were included in this systematic review. Of these, 45 cohort studies were used in the metaanalytical quantitative synthesis of the frequency of PPGL among participants with vHL $(8,15,16,17,18,19,20,21$, 


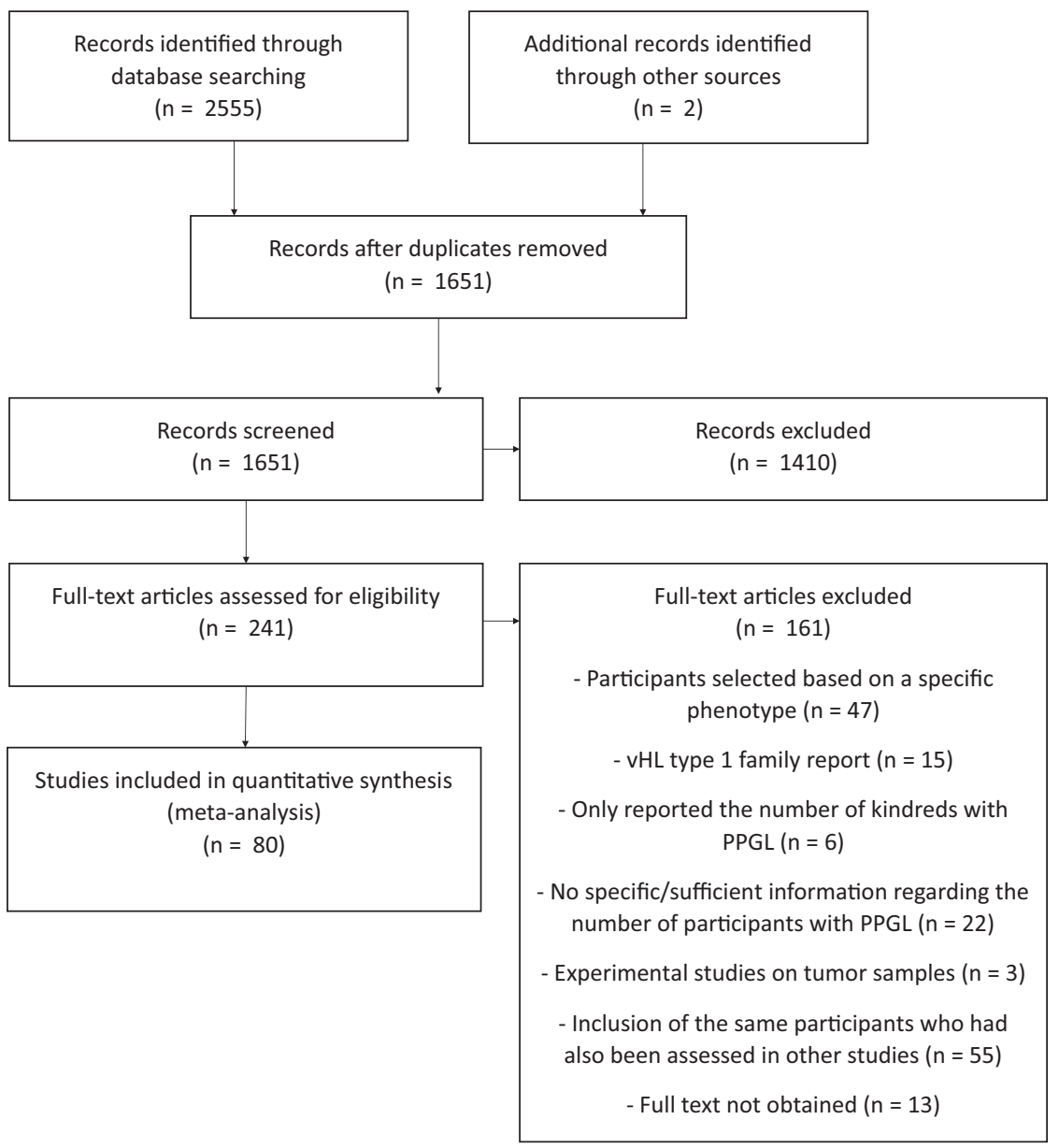

\section{Figure 1}

Preferred Reporting Items for Systematic Reviews and Meta-Analyses (PRISMA) flow diagram illustrating study selection process.
$22,23,24,25,26,27,28,29,30,31,32,33,34,35,36,37$, $38,39,40,41,42,43,44,45,46,47,48,49,50,51,52,53$, $54,55,56,57,58)$. On the other hand, 52 studies were used in the frequency analysis of PPGL in vHL type $2(16,17,21$, $25,26,28,29,35,36,40,44,45,47,48,53,55,56,59,60$, $61,62,63,64,65,66,67,68,69,70,71,72,73,74,75,76,77$, $78,79,80,81,82,83,84,85,86,87,88,89,90,91,92,93)$, of which 24 corresponded to cohort studies $(16,17,21,25$, $26,28,29,35,36,40,44,45,47,48,53,55,56,62,63,64$, $66,77,78,79)$ and 28 to family reports $(59,60,61,65,67$, $68,69,70,71,72,73,74,75,76,80,81,82,83,84,85,86$, $87,88,89,90,91,92,93)$. In total, 17 studies were used in both analyses $(16,17,21,25,26,28,29,35,36,40,44,45$, $47,48,53,55,56)$.

\section{Frequency of PPGL among participants with vHL}

The meta-analysis assessing the frequency of PPGL comprised 45 studies with a total of 4263 participants with vHL $(8,15,16,17,18,19,20,21,22,23,24,25,26$, $27,28,29,30,31,32,33,34,35,36,37,38,39,40,41,42$,
$43,44,45,46,47,48,49,50,51,52,53,54,55,56,57,58)$. Most of these studies were conducted in Europe $(n=21)$ $(8,15,16,17,18,19,20,21,22,23,24,25,26,27,28,29$, $30,31,32,33,34)$, followed by Eastern Asia $(n=14)(35$, 36, 37, 38, 39, 40, 41, 42, 43, 44, 45, 46, 47, 48) and North America $(n=6)(49,50,51,52,53,54)$. All studies assessed patients of all age groups, with the mean age of onset of vHL being 30.6 years (as reported in 13 publications (17, $24,30,31,39,41,43,46,49,50,52,55,58))$ and the mean onset age of PPGL being 28.7 years $(8,21,24,26,31,35$, $40,44,47,49,50,52,55,58)$. Nineteen studies sampled their participants consecutively $(8,16,17,18,19,24,27$, $29,31,32,37,38,39,43,46,49,50,51,52)$, whereas in 11 studies a convenience sample was assessed (20, 21, 22, $25,34,35,45,47,53,56,57)$. A total of 1340 participants - from 25 studies - had information regarding their vHL family history status, of whom 1059 reported having family history of vHL disease $(15,17,22,23$, $24,26,28,29,30,34,37,40,41,42,43,44,45,46,47,48$, $52,53,56,57,58)$. Description of studies can be consulted in Supplementary Table 3, and information regarding (c) 2021 The authors Published by Bioscientifica Ltd
This work is licensed under a Creative Commons Attribution-NonCommercial-NoDerivatives 4.0 Internationab ficense.ifica . com at 04/26/2023 10:18:13AM 
other phenotypic manifestations is displayed in Supplementary Table 4.

The meta-analytical frequency of PPGL among participants with vHL was $19.4 \%(95 \% \mathrm{CI}=15.9-23.6 \%)$, with severe heterogeneity being detected $\left(I^{2}=86.1 \%\right.$, Q Cochran $P$ value $\leq 0.001$ ) (Table 1$)$. In meta-regression analysis (Table 2), studies published in more recent years were associated with a significantly increased frequency of PPGL $(\mathrm{OR}=1.04,95 \% \mathrm{CI}=1.01-1.08, P=0.013)$. No statistically significant differences were observed regarding the mean age of assessed patients ( $\mathrm{OR}=1.05,95 \% \mathrm{CI}=0.96-$ $1.16, P=0.300)$. When assessing the frequency of PPGL in the general cohort of vHL participants, we found significant heterogeneity in all subgroup analyses. Similar results were observed in sensitivity analyses restricted to studies with more than 25 participants (Supplementary Table 5). Similar results were also observed when pooling the meta-analytical frequency of pheochromocytoma (excluding PPGLs) among vHL participants assessed in studies with adequate definition of this outcome (Supplementary Table 6).

The pooled frequency of asymptomatic carriers of $V H L$ pathogenic mutations was $6.2 \%$ (95\% CI $=3.7-10.3 \%$, $\left.I^{2}=84.7 \%, P \leq 0.001\right)(15,16,17,21,23,24,25,26,27,28$, $30,32,33,34,35,36,37,38,39,40,41,42,43,44,45$, $46,47,48,49,50,51,52,53,54,55,56,57,58)$. Among participants with pheochromocytoma, 59.5\% had bilateral synchronous or metachronous disease $(95 \% \mathrm{CI}=47.0$ $\left.70.9 \%, I^{2}=0 \%, P=0.611\right)(20,22,25,26,28,30,35,40,41$, $45,47,55,57,58)$. In addition, $58.3 \%$ participants with PPGL were males (95\% CI $=47.6-68.4 \%, I^{2}=0 \%, P=0.837$ ) $(20,25,26,32,35,37,41,43,44,45,47,52,53,56,58)$.

\section{Frequency of PPGL among participants with vHL type 2}

A total of 52 studies, assessing 840 participants with vHL type 2 , provided information on the frequency of PPGL.
Most of these studies were conducted in Europe $(n=18)(16$, $17,21,25,26,28,29,62,66,68,70,71,72,73,76,83,91$, 92), followed by Eastern Asia $(n=17)(35,36,40,44,45,47$, $48,74,75,77,78,79,80,81,82,86,87)$ and North America $(n=9)(53,59,60,61,63,64,65,69,84)$. All studies assessed patients of all age groups, with the mean onset age of PPGL being 28.8 years (as reported in 21 studies $(21,26,35,40$, $44,47,55,59,60,61,65,67,71,72,74,77,79,85,86,87$, $88)$ ). Six studies reported a consecutive sample $(16,17,29$, $66,77,78)$, whereas in 39 studies a convenience sample was assessed $(21,25,35,45,47,53,56,59,60,61,62,63,64,65$, $67,68,69,70,71,72,73,74,75,76,79,80,81,82,83,84,85$, $86,87,88,89,90,91,92,93)$.

The frequency of PPGL among participants with vHL type 2 was $60.0 \%(95 \% \mathrm{CI}=53.4-66.3 \%)$, with moderate heterogeneity being observed $\left(I^{2}=54.6 \%\right)(16,17,21,25$, $26,28,29,35,36,40,44,45,47,48,53,55,56,59,60,61$, $62,63,64,65,66,67,68,69,70,71,72,73,74,75,76,77$, $78,79,80,81,82,83,84,85,86,87,88,89,90,91,92,93)$ (Table 1). We observed lower heterogeneity in subgroup analyses restricted to convenience sampling $\left(I^{2}=25.6 \%\right)$ and to patients whose diagnosis was performed only clinically $\left(I^{2}=23.1 \%\right)$ (Supplementary Table 7). Similar results were obtained with sensitivity analyses restricted to studies with more than 25 participants (Supplementary Table 5), as well as when assessing the meta-analytical frequency of pheochromocytoma without considering PPGLs (Supplementary Table 6).

Twenty-eight studies, with a total of 411 participants with vHL type $2 \mathrm{~A}$, reported the frequency of PPGL among these patients $(16,25,26,28,29,35,36,47,55,60,61,62,63$, $65,69,70,71,72,73,74,75,78,79,80,81,82,85,92)$. The pooled frequency of PPGL among participants with vHL type $2 \mathrm{~A}$ was $58.2 \%\left(95 \% \mathrm{CI}=49.7-66.3 \%, I^{2}=36.2 \%\right)$ (Table 1) $(16,25,26,28,29,35,36,47,55,60,61,62,63,65,69,70$, $71,72,73,74,75,78,79,80,81,82,85,92)$. In most subgroup analysis, moderate heterogeneity was observed (Table 3 ).

Table 1 Meta-analytical results on the frequency of pheochromocytoma and/or paraganglioma (PPGL) among patients with von Hippel-Lindau disease (vHL).

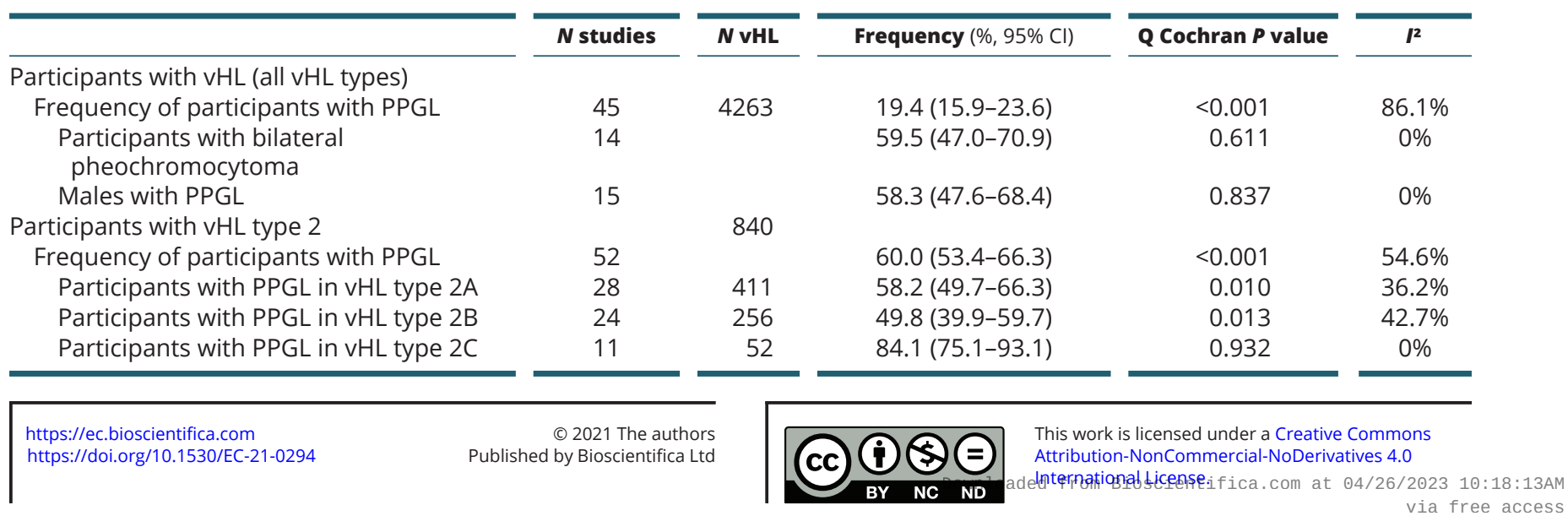


Table 2 Results of meta-regression and subgroup analysis concerning the frequency of pheochromocytoma and/or paraganglioma (PPGL) among patients with von Hippel-Lindau disease ( $\mathrm{VHL}$ ) of all types.

\begin{tabular}{|c|c|c|c|c|c|c|c|}
\hline & \multicolumn{4}{|c|}{ Meta-regression } & \multicolumn{3}{|c|}{ Subgroup analysis } \\
\hline & $N$ studies & $N \mathrm{vHL}$ & OR $(95 \% \mathrm{Cl})$ & $P$ value & Frequency $(\%, 95 \% \mathrm{Cl})$ & $\begin{array}{l}\text { Q Cochran } P \\
\text { value }\end{array}$ & $1^{2}$ \\
\hline Publication year & 45 & 4263 & $1.04(1.01-1.08)$ & $0.013^{*}$ & $-^{a}$ & $-^{a}$ & $-^{a}$ \\
\hline Sample size & 45 & 4263 & $1.00(1.00-1.00)$ & 0.818 & $--^{a}$ & $--^{a}$ & $-^{a}$ \\
\hline$\%$ of males & 24 & 648 & $1.01(0.98-1.03)$ & 0.554 & $-^{a}$ & $-^{a}$ & $-^{a}$ \\
\hline Mean cohort age & 9 & 444 & $1.05(0.96-1.16)$ & 0.300 & $-^{a}$ & $-^{a}$ & $--^{a}$ \\
\hline Mean onset age of vHL & 13 & 1863 & $0.98(0.91-1.07)$ & 0.697 & $--^{a}$ & $-^{a}$ & $-{ }^{a}$ \\
\hline Region & 45 & 4263 & - & $0.802^{\mathrm{b}}$ & & & \\
\hline Europe & 21 & 2148 & $-c$ & $-c$ & $19.1(14.5-24.9)$ & $<0.001$ & $84.4 \%$ \\
\hline Asia and Pacific & 16 & 1116 & $0.97(0.55-1.71)$ & 0.923 & $18.5(12.9-25.9)$ & $<0.001$ & $76.7 \%$ \\
\hline America & 8 & 999 & $1.23(0.62-2.44)$ & 0.558 & $21.0(11.4-35.3)$ & $<0.001$ & $92.6 \%$ \\
\hline Sampling method & 45 & 4263 & - & $0.352^{\mathrm{b}}$ & & & \\
\hline Consecutive & 19 & 3684 & $-c$ & $-c$ & $20.5(16.3-25.5)$ & $<0.001$ & $90.1 \%$ \\
\hline Convenience & 11 & 178 & $1.22(0.61-2.41)$ & 0.576 & $22.4(11.7-38.7)$ & $<0.001$ & $69.4 \%$ \\
\hline Not specified & 15 & 401 & $0.72(0.40-1.28)$ & 0.261 & $15.3(9.9-23.0)$ & $<0.001$ & $61.2 \%$ \\
\hline Diagnosis method & 45 & 4263 & - & $0.888^{\mathrm{b}}$ & & & \\
\hline $\begin{array}{l}\text { Included genetic } \\
\text { testing/not specified }\end{array}$ & 42 & 4086 & $-c$ & $-c$ & $19.7(16.1-23.8)$ & $<0.001$ & $85.0 \%$ \\
\hline Clinical criteria only & 3 & 177 & $0.93(0.32-2.70)$ & 0.888 & $27.7(3.2-81.6)$ & $<0.001$ & $91.8 \%$ \\
\hline
\end{tabular}

${ }^{a}$ Not performed, as this is a continuous variable; ${ }^{b}$ Omnibus $P$ value for this variable; 'Reference category; *Statistically significant $P$ value.

Twenty-four studies, with a total of 256 participants with vHL type $2 \mathrm{~B}$, reported the frequency of PPGL among these patients $(21,29,36,40,44,45,48,53,55,56,64,66,67$, $68,72,77,78,83,84,86,88,89,91,93)$. The meta-analytical frequency of PPGL among participants with vHL type $2 \mathrm{~B}$ was $49.8 \%\left(95 \% \mathrm{CI}=39.9-59.7 \%, I^{2}=42.7 \%\right)(21,29,36,40$, $44,45,48,53,55,56,64,66,67,68,72,77,78,83,84,86,88$, $89,91,93$ ) (Table 1). Low or undetectable heterogeneity was observed when performing subgroup analyses restricted to European studies (pooled frequency $=37.8 \%, 95 \% \mathrm{CI}=27.8$ - $\left.48.9 \%, P=0.778, I^{2}=0 \%\right)$ or to studies using convenience sampling (pooled frequency $=55.9 \%, 95 \% \mathrm{CI}=46.1-65.2 \%$, $P=0.135, I^{2}=12.7 \%$ ) (Table 4). All other tested covariates were associated with moderate heterogeneity.

Lastly, in 11 studies, with a total of 52 participants with vHL type $2 \mathrm{C}$, information was provided on the frequency of PPGL among these patients $(25,26,29,40,44,45,59$, $74,76,87,90)$. The meta-analytical frequency was $84.1 \%$ $(95 \% \mathrm{CI}=75.1-93.1 \%)$, with no heterogeneity observed $\left(I^{2}=0 \%\right)(25,26,29,40,44,45,59,74,76,87,90)$ (Table 1).

Table 3 Results of meta-regression and subgroup analysis concerning the frequency of pheochromocytoma and/or paraganglioma (PPGL) among patients with von Hippel-Lindau disease (vHL) type 2A.

\begin{tabular}{|c|c|c|c|c|c|c|c|}
\hline & \multicolumn{4}{|c|}{ Meta-regression } & \multicolumn{3}{|c|}{ Subgroup analysis } \\
\hline & $N$ studies & $N \mathrm{vHL}$ & OR $(95 \% \mathrm{Cl})$ & $P$ value & Frequency $(\%, 95 \% \mathrm{Cl})$ & $\begin{array}{l}\text { Q Cochran } p \\
\text { value }\end{array}$ & $P^{2}$ \\
\hline Publication year & 28 & 411 & $0.98(0.93-1.03)$ & 0.384 & $-^{a}$ & $-^{a}$ & $-{ }^{a}$ \\
\hline Sample size & 28 & 411 & $1.00(0.99-1.01)$ & 0.573 & $-^{a}$ & $-^{a}$ & $--^{a}$ \\
\hline Region & 28 & 411 & - & $0.306^{b}$ & $--^{a}$ & $--^{a}$ & $--^{a}$ \\
\hline Europe & 11 & 255 & $-c$ & $-c$ & 59.6 (48.9-69.5) & $<0.165$ & $35.4 \%$ \\
\hline Asia and Pacific & 11 & 69 & $0.60(0.25-1.41)$ & 0.239 & $48.8(32.3-65.5)$ & 0.135 & $32.2 \%$ \\
\hline America & 6 & 87 & $1.29(0.48-3.44)$ & 0.617 & $73.4(37.2-92.8)$ & 0.009 & $80.1 \%$ \\
\hline Sampling method & 28 & 411 & - & $0.118^{b}$ & & & \\
\hline Consecutive & 3 & 24 & $--^{c}$ & $-{ }^{c}$ & $55.8(24.3-83.2)$ & 0.142 & $50.3 \%$ \\
\hline Convenience & 21 & 370 & $0.99(0.32-3.01)$ & 0.981 & $56.1(47.4-64.5)$ & 0.012 & $33.9 \%$ \\
\hline Not specified & 4 & 17 & $5.39(0.81-35.76)$ & 0.081 & $87.6(61.0-97.0)$ & 0.767 & $0 \%$ \\
\hline Diagnosis & 28 & 411 & - & $0.427^{b}$ & & & \\
\hline $\begin{array}{l}\text { Included genetic } \\
\text { testing/not specified }\end{array}$ & 27 & 409 & $-^{c}$ & $-{ }^{c}$ & $57.9(49.3-66.0)$ & 0.008 & $36.9 \%$ \\
\hline Clinical criteria only & 1 & 2 & $2.69(0.38-19.08)$ & 0.427 & 83.3 (19.4-99.0) & $<0.001$ & $0 \%$ \\
\hline
\end{tabular}

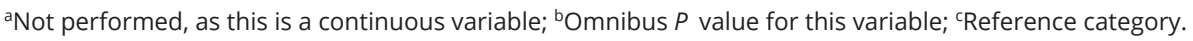

https://ec.bioscientifica.com https://doi.org/10.1530/EC-21-0294 (c) 2021 The authors Published by Bioscientifica Ltd

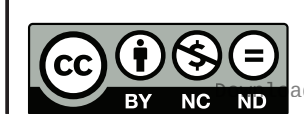

This work is licensed under a Creative Commons Attribution-NonCommercial-NoDerivatives 4.0 International License.ifica com at $04 / 26 / 2023$ 10:18:13AM 
Table 4 Results of meta-regression and subgroup analysis concerning the frequency of pheochromocytoma and/or paraganglioma (PPGL) among patients with von Hippel-Lindau disease (VHL) type $2 \mathrm{~B}$.

\begin{tabular}{|c|c|c|c|c|c|c|c|}
\hline & \multicolumn{4}{|c|}{ Meta-regression } & \multicolumn{3}{|c|}{ Subgroup analysis } \\
\hline & $N$ studies & $\mathrm{N} \mathrm{vHL}$ & OR $(95 \% \mathrm{Cl})$ & $P$ value & Frequency $(\%, 95 \% \mathrm{Cl})$ & Cochran $P$ value & 12 \\
\hline Publication year & 24 & 256 & $1.00(0.95-1.05)$ & 0.965 & $-^{a}$ & $-^{a}$ & $-^{a}$ \\
\hline Sample size & 24 & 256 & $1.00(0.96-1.04)$ & 0.975 & $--^{a}$ & $-^{a}$ & $--^{a}$ \\
\hline Region & 24 & 256 & - & $0.138^{b}$ & $--^{a}$ & $--^{a}$ & $-^{a}$ \\
\hline Europe & 7 & 83 & $--^{c}$ & $--^{c}$ & 37.8 (27.8-48.9) & 0.778 & $0 \%$ \\
\hline Asia and Pacific & 11 & 105 & $1.97(0.85-4.57)$ & 0.112 & $55.0(39.3-70.0)$ & 0.066 & $45.2 \%$ \\
\hline America & 6 & 68 & $2.55(0.91-7.12)$ & 0.074 & $58.8(30.4-82.4)$ & 0.052 & $58.0 \%$ \\
\hline Sampling method & 24 & 256 & - & $0.361^{\mathrm{b}}$ & & & \\
\hline Consecutive & 4 & 62 & $--^{c}$ & $-^{c}$ & $45.6(24.0-69.0)$ & 0.094 & $59.1 \%$ \\
\hline Convenience & 15 & 155 & $1.48(0.58-3.80)$ & 0.412 & $55.9(46.1-65.2)$ & 0.135 & $12.7 \%$ \\
\hline Not specified & 5 & 39 & $0.72(0.21-2.51)$ & 0.606 & $40.8(17.2-69.4)$ & 0.118 & $47.7 \%$ \\
\hline Diagnosis & 24 & 256 & - & $0.301^{\mathrm{b}}$ & & & \\
\hline $\begin{array}{l}\text { Included genetic testing/ } \\
\text { not specified }\end{array}$ & 20 & 222 & $-^{c}$ & $-^{c}$ & $46.2(35.8-56.9)$ & 0.021 & $44.4 \%$ \\
\hline Clinical criteria only & 4 & 34 & $2.04(0.70-5.92)$ & 0.301 & 73.5 (45.7-90.0) & 0.272 & $29.6 \%$ \\
\hline
\end{tabular}

${ }^{a}$ Not performed, as this is a continuous variable; ${ }^{b}$ Omnibus $P$ value for this variable; 'Reference category.

\section{Risk of bias assessment}

All studies had at least one high risk of bias item concerning internal validity (Fig. 2). Ten studies (12.5\%) had low risk of bias in all items concerning external validity (16, $17,18,24,27,29,31,38,49,51)$. The two items for which studies were most commonly classified as having 'low risk of bias' concerned the possibility of nonresponse bias (97.5\%) and the presentation of an appropriate numerator and denominator for the parameter of interest (97.5\%). Conversely, the case definition was the item for which studies were most frequently classified as having 'high risk of bias', with only two studies (2.5\%) using an acceptable case definition $(55,71) .44 \%$ of all included studies were considered representative of the target population. However, this percentage rises to $73 \%$ when analyzing only those 45 cohort studies used in the meta-analysis pooling the frequency of PPGL in patients with vHL of any subtype. On the other hand, only $23 \%$ studies are considered representative of the target population when considering solely those studies assessing the frequency of PPGL in patients with vHL type 2 .

\section{Discussion}

In this systematic review, we assessed the frequency of PPGL in patients with vHL, as well as in patients with each subtype of vHL. The meta-analytical frequency of PPGL in patients with vHL was $19 \%$, which is in agreement with previous estimates $(11,31)$. This frequency increased to $60 \%$ in vHL type 2 participants and was determined to be 58,50 , and $84 \%$ among participants with vHL type $2 \mathrm{~A}$, type $2 \mathrm{~B}$, and type $2 \mathrm{C}$, respectively. Most participants who developed pheochromocytoma had bilateral adrenal involvement (60\%), including both synchronous and metachronous processes. Overall, these results point to the high frequency of PPGL among patients with vHL (particularly in patients belonging to type 2 families, in whom this frequency is exceptionally high), as well as

\section{Representation national population}

Representation target population

Random/consecutive sampling

Non-response bias

Acceptable case definition

Same data collection method

Numbers appropriate

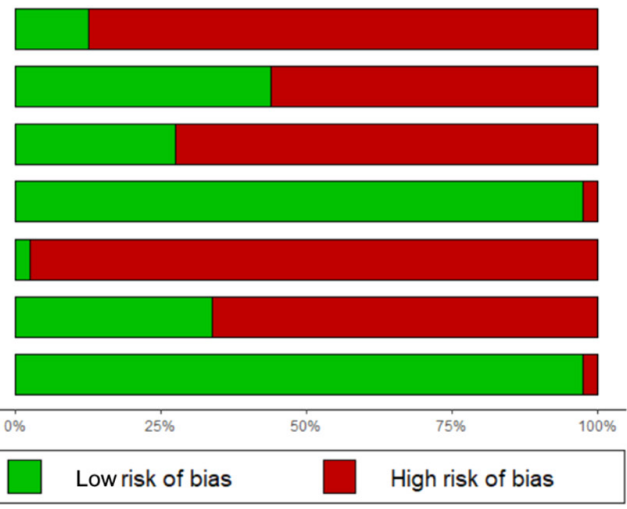

\section{Figure 2}

Risk of bias graph depicting the assessment of the methodological quality of included primary studies. Risk of study bias items assessed: aStudy's target population as a close representation of the vHL national population. 'bampling frame as a true or close representation of the target population. 'Sample selection based on a random/consecutive process. 'Likelihood of nonresponse bias. ${ }^{\mathrm{e}}$ Acceptable case definition used in the study. fSame mode of evaluation for all subjects. gNumerator and denominator appropriate. https://ec.bioscientifica.com https://doi.org/10.1530/EC-21-0294 (c) 2021 The authors Published by Bioscientifica Ltd
This work is licensed under a Creative Commons Attribution-NonCommercial-NoDerivatives 4.0 Internationab ficense.ifica . com at 04/26/2023 10:18:13AM 
to a high propensity for bilateral adrenal involvement, supporting the benefit of lifetime screening for PPGL in patients with vHL. Meta-regression analysis revealed that more recent studies were associated with a higher frequency of PPGL, which is likely related to an improvement in diagnostic procedures for PPGL and to the expanding application of annual screening protocols in vHL patients. We found no statistically significant differences regarding the mean age of assessed patients - in this setting, it would be expected for studies assessing cohorts of older patients to be associated with a higher frequency of PPGL, as the disease penetrance increases with age, being estimated to be as high as $95 \%$ by 60 years of age (49). However, the interpretation of this analysis may be limited by the fact that we used the mean cohort age rather than individual patient-level information regarding participants' age. Additionally, it should be noted that the mean age of onset of PPGL of 28.7 years, in the upper end of the third decade of life, probably reflects a substantial number of clinically diagnosed cases, compared to the genetic screening and surveillance that increasingly allow for earlier diagnosis.

This study has some limitations. Firstly, most primary studies did not present clear outcome definitions, with some using the term 'pheochromocytoma' to broadly refer to tumors arising from adrenal and extra-adrenal chromaffin cells, others using the term to strictly refer to tumors of adrenomedullary origin, and others not appropriately defining the term. To tackle this limitation, our outcome variable corresponded to PPGL rather than pheochromocytoma. Secondly, some primary studies reported single-institution experiences with small sample series, possibly consisting of a reduced number of families, which conveys a risk of overrepresentation of certain vHL subtypes - to account for this limitation, we performed sensitivity analyses restricted to studies with more than 25 participants, with similar results being observed. Additionally, we came across some studies that disclosed only the number of families with vHL type 2 phenotype rather than the number of participants with PPGL - these reports could not be included in the quantitative synthesis. Another limitation concerns the possibility of selection bias, particularly in the calculation of the frequency of PPGL in vHL type 2C participants - as discussed earlier, to account for the fact that PPGL is the only phenotypic manifestation in the rare vHL type $2 \mathrm{C}$ and, therefore, the diagnostic feature in the clinical diagnosis of this subtype, we included only primary studies that have tested asymptomatic members of vHL type $2 \mathrm{C}$ families for germline pathogenic $V H L$ mutations; however, in most cases, the testing coverage of the pedigree was not disclosed and therefore it is likely that some members were not tested. This fact combined with the limited number of studies assessing vHL type $2 \mathrm{C}$ participants may have contributed to an overestimation of the frequency of PPGL in this subtype. Another limitation concerns the recently described germline mutations in the E1' cryptic exon of the VHL gene in patients previously considered mutation negative, consisting of a small subset of patients possibly not assessed in the studies included in this meta-analysis (94). Another limitation concerns the lack of important information provided by primary studies, namely regarding sociodemographic data of the vHL participants and adequate characterization of PPGL when these occurred (i.e. mean age of onset, data regarding recurrences or second primary tumors, and data regarding biochemical and imaging procedures). As a result, we were not able to assess several variables that could potentially contribute to explain heterogeneity. Another limitation concerns the fact that information regarding the rate of metastatic PPGL arising in vHL patients was not included in the scope of the query used in this study. In result, the majority of included studies did not provide specific information regarding this subject, preventing from drawing reliable conclusions on this topic. Finally, another important limitation concerns the methodological quality of included primary studies, with all of them having at least one high risk of bias item concerning internal validity.

This study also has several strengths. We conducted a search using three electronic bibliographic databases and did not apply date- or language-based exclusion criteria, so as to minimize the risk of publication bias. We also performed meta-regression and subgroup analysis to identify variables responsible for explaining across-studies heterogeneity. In addition, we assessed the methodological quality of included primary studies, pointing that future primary studies should particularly minimize the risk of bias related to the use of equivocal outcome definitions and disclose more detailed patientlevel information, namely regarding the development and coexpression of manifestations, for further establishment of phenotypic associations in frame with the genetic findings. Finally, the results of this systematic review have clinical relevance, as they provide additional information for the endocrinological management of vHL patients and their respective families, supporting the benefit of early and lifetime screening for PPGL, as the review points that PPGL is more frequent than that acknowledged in some of the previous reports, particularly among type 2 vHL families.

This work is licensed under a Creative Commons Attribution-NonCommercial-NoDerivatives 4.0 International License ifica com at $04 / 26 / 2023$ 10:18:13AM 


\section{Conclusions}

In conclusion, PPGL is frequent among patients with vHL, with this frequency being higher among patients with vHL type 2 (in whom it ranges, according to the subtype, from 50 to 84\%). Overall, this points to a high burden of PPGL among patients with vHL, indirectly supporting early and lifetime screening. Nevertheless, our results should be carefully interpreted on account of the observed heterogeneity and on the important methodological limitations observed in primary studies. For the future, an eventual development of an international vHL register could contribute to overcome such limitations, as it would allow for clinicians and researchers to access genotypicphenotypic information, benefiting the individual and collective management of the vHL disease, as a day-to-day clinical tool and as a data record for future studies.

\section{Supplementary materials}

This is linked to the online version of the paper at https://doi.org/10.1530/ EC-21-0294.

\section{Declaration of interest}

The authors declare that there is no conflict of interest that could be perceived as prejudicing the impartiality of the research reported.

\section{Funding}

This work did not receive any specific grant from any funding agency in the public, commercial, or not-for-profit sector.

\section{Data sharing statement}

Additional data will be available for other researchers upon reasonable request to the corresponding author.

\section{References}

1 Choyke PL, Glenn GM, Walther MM, Patronas NJ, Linehan WM \& Zbar B. Von Hippel-Lindau disease: genetic, clinical, and imaging features. Radiology 1995194 629-642. (https://doi.org/10.1148/ radiology.194.3.7862955)

2 Binderup MLM, Galanakis M, Budtz-Jorgensen E, Kosteljanetz M $\&$ Bisgaard ML. Prevalence, birth incidence, and penetrance of von Hippel-Lindau disease (vHL) in Denmark. European Journal of Human Genetics 201725 301-307. (https://doi.org/10.1038/ejhg.2016.173)

3 Wachtel H \& Fishbein L. Genetics of pheochromocytoma and paraganglioma. Current Opinion in Endocrinology, Diabetes, and Obesity 202128 283-290. (https://doi.org/10.1097/MED.0000000000000634)

4 Juhlin CC. Challenges in paragangliomas and pheochromocytomas: from histology to molecular immunohistochemistry. Endocrine Pathology 202132 228-244. (https://doi.org/10.1007/s12022-021-09675-0)

5 Prasad R, Johnston LB, Savage MO, Martin L, Perry LA \& Storr HL. Pediatric endocrine screening for von Hippel-Lindau disease: benefits and the challenge of compliance. Journal of Endocrinological Investigation 201134 296-299. (https://doi.org/10.1007/BF03347089)

6 Nordstrom-O'Brien M, Van Der Luijt RB, Van Rooijen E, Van Den Ouweland AM, Majoor-Krakauer DF, Lolkema MP, Van Brussel A, Voest EE
\& Giles RH. Genetic analysis of von Hippel-Lindau disease. Human Mutation 201031 521-537. (https://doi.org/10.1002/humu.21219)

7 Crespigio J, Berbel LCL, Dias MA, Berbel RF, Pereira SS, Pignatelli D \& Mazzuco TL. Von Hippel-Lindau disease: a single gene, several hereditary tumors. Journal of Endocrinological Investigation 201841 21-31. (https://doi.org/10.1007/s40618-017-0683-1)

8 Feletti A, Anglani M, Scarpa B, Schiavi F, Boaretto F, Zovato S, Taschin E, Gardi M, Zanoletti E, Piermarocchi S, et al. Von Hippel-Lindau disease: an evaluation of natural history and functional disability. NeuroOncology 201618 1011-1020. (https://doi.org/10.1093/neuonc/nov313)

9 Baghai M, Thompson GB, Young Jr WF, Grant CS, Michels VV \& van Heerden JA. Pheochromocytomas and paragangliomas in von HippelLindau disease: a role for laparoscopic and cortical-sparing surgery. Archives of Surgery 2002137 682-688; discussion 688-689. (https://doi. org/10.1001/archsurg.137.6.682)

10 Neumann HPH, Tsoy U, Bancos I, Amodru V, Walz MK, Tirosh A, Kaur RJ, McKenzie T, Qi X, Bandgar T, et al. Comparison of pheochromocytoma-specific morbidity and mortality among adults with bilateral pheochromocytomas undergoing total adrenalectomy vs cortical-sparing adrenalectomy. JAMA Network Open 20192 e198898. (https://doi.org/10.1001/jamanetworkopen.2019.8898)

11 Binderup ML, Bisgaard ML, Harbud V, Moller HU, Gimsing S, FriisHansen L, Hansen Tv, Bagi P, Knigge U, Kosteljanetz M, et al. Von Hippel-Lindau disease (vHL) National Clinical Guideline for diagnosis and surveillance in Denmark, 3rd edition. Danish Medical Journal 2013 60 B4763.

12 Moher D, Liberati A, Tetzlaff J, Altman DG \& PRISMA Group. Preferred reporting items for systematic reviews and meta-analyses: the PRISMA statement. PLOS Medicine 20096 e1000097. (https://doi.org/10.1371/ journal.pmed.1000097)

13 Lenders JW, Duh QY, Eisenhofer G, Gimenez-Roqueplo AP, Grebe SK, Murad MH, Naruse M, Pacak K, Young Jr WF \& Endocrine Society. Pheochromocytoma and paraganglioma: an endocrine society clinical practice guideline. Journal of Clinical Endocrinology and Metabolism 201499 1915-1942. (https://doi.org/10.1210/jc.2014-1498)

14 Hoy D, Brooks P, Woolf A, Blyth F, March L, Bain C, Baker P, Smith E $\&$ Buchbinder R. Assessing risk of bias in prevalence studies: modification of an existing tool and evidence of interrater agreement. Journal of Clinical Epidemiology 201265 934-939. (https://doi. org/10.1016/j.jclinepi.2011.11.014)

15 Ciotti P, Garuti A, Gulli R, Ballestrero A, Bellone E \& Mandich P. Germline mutations in the von Hippel-Lindau gene in Italian patients. European Journal of Medical Genetics 200952 311-314. (https:// doi.org/10.1016/j.ejmg.2009.05.007)

16 Cybulski C, Krzystolik K, Murgia A, Gorski B, Debniak T, Jakubowska A Martella M, Kurzawski G, Prost M, Kojder I, et al. Germline mutations in the von Hippel-Lindau (VHL) gene in patients from Poland: disease presentation in patients with deletions of the entire VHL gene. Journal of Medical Genetics 200239 E38. (https://doi.org/10.1136/jmg.39.7.e38)

17 Dollfus H, Massin P, Taupin P, Nemeth C, Amara S, Giraud S, Beroud C, Dureau P, Gaudric A, Landais P, et al. Retinal hemangioblastoma in von Hippel-Lindau disease: a clinical and molecular study. Investigative Ophthalmology and Visual Science 200243 3067-3074.

18 Erlic Z, Ploeckinger U, Cascon A, Hoffmann MM, von Duecker L, Winter A Kammel G, Bacher J, Sullivan M, Isermann B, et al. Systematic comparison of sporadic and syndromic pancreatic islet cell tumors. Endocrine-Related Cancer 201017 875-883. (https://doi.org/10.1677/ERC-10-0037)

19 O’Brien FJ, Danapal M, Jairam S, Lalani AK, Cunningham J, Morrin M, McNally S, Donovan MG, Little D, Tuthill A, et al. Manifestations of Von Hippel Lindau syndrome: a retrospective national review. QJM 2014107 291-296. (https://doi.org/10.1093/qjmed/hct249)

20 Frantzen C, Kruizinga RC, van Asselt SJ, Zonnenberg BA, Lenders JW, de Herder WW, Walenkamp AM, Giles RH, Hes FJ, Sluiter WJ, et al. Pregnancy-related hemangioblastoma progression and complications in von Hippel-Lindau disease. Neurology 201279 793-796. (https://doi. org/10.1212/WNL.0b013e3182661f3c) 
21 Gergics P, Patocs A, Toth M, Igaz P, Szucs N, Liko I, Fazakas F, Szabo I, Kovacs B, Glaz E, et al. Germline VHL gene mutations in Hungarian families with von Hippel-Lindau disease and patients with apparently sporadic unilateral pheochromocytomas. European Journal of Endocrinology 2009161 495-502. (https://doi.org/10.1530/EJE-09-0399)

22 Graziani R, Mautone S, Vigo M, Manfredi R, Opocher G \& Falconi M. Spectrum of magnetic resonance imaging findings in pancreatic and other abdominal manifestations of von Hippel-Lindau disease in a series of 23 patients: a pictorial review. JOP 201415 1-18. (https://doi. org/10.6092/1590-8577/1757)

23 Losonczy G, Fazakas F, Pfliegler G, Komaromi I, Balazs E, Penzes K \& Berta A. Three novel germ-line VHL mutations in Hungarian von Hippel-Lindau patients, including a nonsense mutation in a fifteenyear-old boy with renal cell carcinoma. BMC Medical Genetics 201314 3. (https://doi.org/10.1186/1471-2350-14-3)

24 Maher ER, Yates JR, Harries R, Benjamin C, Harris R, Moore AT \& Ferguson-Smith MA. Clinical features and natural history of von Hippel-Lindau disease. Quarterly Journal of Medicine 199077 1151-1163. (https://doi.org/10.1093/qjmed/77.2.1151)

25 Stanojevic BR, Lohse P, Neskovic GG, Damjanovic SM, Novkovic TB, Jovanovic-Cupic SP \& Dimitrijevic BB. Germline VHL gene mutations in three Serbian families with von Hippel-Lindau disease. Neoplasma 200754 402-406.

26 Wittstrom E, Nordling M \& Andreasson S. Genotype-phenotype correlations, and retinal function and structure in von Hippel-Lindau disease. Ophthalmic Genetics 201435 91-106. (https://doi.org/10.3109/ 13816810.2014.886265)

27 Binderup MLM. Von Hippel-Lindau disease: diagnosis and factors influencing disease outcome. Danish Medical Journal 201865 B5461.

28 Glushkova M, Dimova P, Yordanova I, Todorov T, Tourtourikov I, Mitev V \& Todorova A. Molecular-genetic diagnostics of von HippelLindau syndrome (VHL) in Bulgaria: first complex mutation event in the VHL gene. International Journal of Neuroscience 2018128 117-124. (https://doi.org/10.1080/00207454.2017.1372436)

29 Hes FJ, van der Luijt RB, Janssen ALW, Zewald RA, De Jong GJ, Lenders JW, Links TP, Luyten GPM, Sijmons RH, Eussen HJ, et al. Frequency of von Hippel-Lindau germline mutations in classic and non-classic von HippelLindau disease identified by DNA sequencing, Southern blot analysis and multiplex ligation-dependent probe amplification. Clinical Genetics 2007 72 122-129. (https://doi.org/10.1111/j.1399-0004.2007.00827.x)

30 Ruiz-Llorente S, Bravo J, Cebrián A, Cascón A, Pollan M, Tellería D, Letón R, Urioste M, Rodríguez-López R, De Campos JM, et al. Genetic characterization and structural analysis of VHL Spanish families to define genotype-phenotype correlations. Human Mutation 200423 160-169. (https://doi.org/10.1002/humu.10309)

31 Ong KR, Woodward ER, Killick P, Lim C, Macdonald F \& Maher ER. Genotype-phenotype correlations in von Hippel-Lindau disease. Human Mutation 200728 143-149. (https://doi.org/10.1002/humu.20385)

32 Prasad V, Tiling N, Denecke T, Brenner W \& Plöckinger U. Potential role of $68 \mathrm{Ga}$-DOTATOC PET/CT in screening for pancreatic neuroendocrine tumour in patients with von Hippel-Lindau disease. European Journal of Nuclear Medicine and Molecular Imaging 201643 2014-2020. (https://doi.org/10.1007/s00259-016-3421-6)

33 Vanbinst AM, Brussaard C, Vergauwen E, Van Velthoven V, Kuijpers R, Michel O, Foulon I, Jansen AC, Lefevere B, Bohler S, et al. A focused 35-minute whole body MRI screening protocol for patients with von Hippel-Lindau disease. Hereditary Cancer in Clinical Practice 20191722. (https://doi.org/10.1186/s13053-019-0121-9)

34 Wiklund L, Nordling M, Wahlström J, Engwall Y \& Martinsson T. Novel germline mutations in Swedish von Hippel-Lindau disease patients. International Journal of Oncology 199711 509-512. (https:// doi.org/10.3892/ijo.11.3.509)

35 Chen J, Geng W, Zhao Y, Zhao H, Wang G, Huang F, Liu F \& Geng X. Clinical and mutation analysis of four Chinese families with von Hippel-Lindau disease. Clinical and Translational Oncology 201315 391-397. (https://doi.org/10.1007/s12094-012-0940-x)
36 Hattori K, Teranishi J, Stolle C, Yoshida M, Kondo K, Kishida T, Kanno H, Baba M, Kubota Y \& Yao M. Detection of germline deletions using real-time quantitative polymerase chain reaction in Japanese patients with von Hippel-Lindau disease. Cancer Science 200697 400-405. (https://doi.org/10.1111/j.1349-7006.2006.00193.x)

37 Hwang S, Ku CR, Lee JI, Hur KY, Lee MS, Lee CH, Koo KY, Lee JS \& Rhee Y. Germline mutation of Glu70Lys is highly frequent in Korean patients with von Hippel-Lindau (VHL) disease. Journal of Human Genetics 201459 488-493. (https://doi.org/10.1038/jhg.2014.61)

38 Igarashi H, Ito T, Nishimori I, Tamura K, Yamasaki I, Tanaka M \& Shuin T. Pancreatic involvement in Japanese patients with von HippelLindau disease: results of a nationwide survey. Journal of Gastroenterology 201449 511-516. (https://doi.org/10.1007/s00535-013-0794-1)

39 Kwon T, Jeong IG, Pak S, You D, Song C, Hong JH, Ahn H \& Kim CS. Renal tumor size is an independent prognostic factor for overall survival in von Hippel-Lindau disease. Journal of Cancer Research and Clinical Oncology 2014140 1171-1177. (https://doi.org/10.1007/s00432-014-1654-y)

40 Siu WK, Ma RCW, Lam CW, Mak CM, Yuen YP, Lo FMI, Chan KW, Lam SF, Ling SC, Tong SF, et al. Molecular basis of von Hippel-Lindau syndrome in Chinese patients. Chinese Medical Journal $2011 \mathbf{1 2 4}$ 237-241. (https://doi.org/10.3760/cma.j.issn.0366-6999.2011.02.016)

41 Sriphrapradang C, Choopun K, Tunteeratum A \& Sura T. Genotypephenotype correlation in patients with germline mutations of VHL, RET, SDHB, and SDHD genes: Thai experience. Clinical Medicine Insights: Endocrinology and Diabetes 2017101179551417705122. (https://doi.org/10.1177/1179551417705122)

42 Huang JS, Huang CJ, Chen SK, Chien CC, Chen CW \& Lin CM. Associations between VHL genotype and clinical phenotype in familial von Hippel-Lindau disease. European Journal of Clinical Investigation 200737 492-500. (https://doi.org/10.1111/j.13652362.2007.01806.x)

43 Kim WT, Ham WS, Park SJ, Kim SW, Lee Js, Lee JS, Ju HJ \& Choi YD. Clinical characteristics of renal cell carcinoma in Korean patients with von Hippel-Lindau disease. Korean Journal of Urology 200849 863-867. (https://doi.org/10.4111/kju.2008.49.10.863)

44 Lee JS, Lee JH, Lee KE, Kim JH, Hong JM, Ra EK, Seo SH, Lee SJ, Kim MJ, Park SS, et al. Genotype-phenotype analysis of von Hippel-Lindau syndrome in Korean families: HIF-alpha binding site missense mutations elevate age-specific risk for CNS hemangioblastoma. BMC Medical Genetics 201617 48. (https://doi.org/10.1186/s12881-016-0306-2)

45 Liu QL, Yuan G, Tong DL, Liu GL, Yi YT, Zhang J, Zhang Y, Wang LA, Wang LF, Zhang DZ, et al. Novel genotype-phenotype correlations in five Chinese families with von Hippel-Lindau disease. Endocrine Connections 20187 870-878. (https://doi.org/10.1530/EC-18-0167)

46 Wang JY, Peng SH, Li T, Ning XH, Liu SJ, Hong BA, Liu JY, Wu PJ, Zhou BW, Zhou JC, et al. Risk factors for survival in patients with von Hippel-Lindau disease. Journal of Medical Genetics 201855 322-328. (https://doi.org/10.1136/jmedgenet-2017-104995)

47 Wang Y, Liang G, Tian J, Wang X, Chen A, Liang T, Du Y, Li H, Du J, Yu L, et al. Pedigree analysis, diagnosis and treatment in von HippelLindau syndrome: a report of three cases. Oncology Letters 201815 4882-4890. (https://doi.org/10.3892/ol.2018.7957)

48 Zhang J, Huang YR, Pan JH, Liu DM, Zhou LX, Xue W, Chen Q, Dong BJ \& Xuan HQ. Germline mutations in the von Hippel-Lindau disease (VHL) gene in mainland Chinese families. Journal of Cancer Research and Clinical Oncology 2008134 1211-1218. (https://doi. org/10.1007/s00432-008-0399-x)

49 Aufforth RD, Ramakant P, Sadowski SM, Mehta A, TrebskaMcGowan K, Nilubol N, Pacak K \& Kebebew E. Pheochromocytoma screening initiation and frequency in von Hippel-Lindau syndrome. Journal of Clinical Endocrinology and Metabolism 2015100 4498-4504. (https://doi.org/10.1210/jc.2015-3045)

50 Bradley S, Dumas N, Ludman M \& Wood L. Hereditary renal cell carcnoma associated with von Hippel-Lindau disease: a description of a nova Scotia cohort. Journal of the Canadian Urological Association 20093 32-36. (https://doi.org/10.5489/cuaj.1013) 
51 Chen F, Kishida T, Yao M, Hustad T, Glavac D, Dean M, Gnarra JR, Orcutt ML, Duh FM \& Glenn G. Germline mutations in the von Hippel-Lindau disease tumor suppressor gene: correlations with phenotype. Human Mutation 19955 66-75. (https://doi.org/10.1002/ humu.1380050109)

52 Salama Y, Albanyan S, Szybowska M, Bullivant G, Gallinger B, Giles RH, Asa S, Badduke C, Chiorean A, Druker H, et al. Comprehensive characterization of a Canadian cohort of von HippelLindau disease patients. Clinical Genetics 201996 461-467. (https:// doi.org/10.1111/cge.13613)

53 Chacon-Camacho OF, Rodriguez-Dennen F, Camacho-Molina A, Rasmussen A, Alonso-Vilatela E \& Zenteno JC. Clinical and molecular features of familial and sporadic cases of von Hippel-Lindau disease from Mexico. Clinical and Experimental Ophthalmology 201038 277-283. (https://doi.org/10.1111/j.1442-9071.2010.02241.x)

54 Rasmussen A, Alonso E, Ochoa A, De Biase I, Familiar I, Yescas P, Sosa AL, Rodriguez Y, Chavez M, Lopez-Lopez M, et al. Uptake of genetic testing and long-term tumor surveillance in von Hippel-Lindau disease. BMC Medical Genetics 201011 4. (https://doi.org/10.1186/1471-2350-11-4)

55 Fagundes GFC, Petenuci J, Lourenco Jr DM, Trarbach EB, Pereira MAA Correa D'Eur JE, Hoff AO, Lerario AM, Zerbini MCN, Siqueira S, et al. New insights Into pheochromocytoma surveillance of young patients with VHL missense mutations. Journal of the Endocrine Society 20193 1682-1692. (https://doi.org/10.1210/js.2019-00225)

56 Gomy I, Molfetta GA, De Andrade Barreto E, Ferreira CA, Zanette DL, Casali-Da-Rocha JC \& Silva Jr WA. Clinical and molecular characterization of Brazilian families with von Hippel-Lindau disease: a need for delineating genotype-phenotype correlation. Familial Cancer 20109 635-642. (https://doi.org/10.1007/s10689-010-9357-2)

57 K GH, Gopal RA, George J, Bandgar T, Menon P \& Shah N. Von Hippel-Lindau disease: a case series of unusual familial cancer syndrome. Endocrinologist 201020 134-136. (https://doi.org/10.1097/ TEN.0b013e3181dfdc98)

58 Vikkath N, Valiyaveedan S, Nampoothiri S, Radhakrishnan N, Pillai GS, Nair V, Pooleri GK, Mathew G, Menon KN, Ariyannur PS, et al. Genotype-phenotype analysis of von Hippel-Lindau syndrome in fifteen Indian families. Familial Cancer 201514 585-594. (https:// doi.org/10.1007/s10689-015-9806-z)

59 Abbott MA, Nathanson KL, Nightingale S, Maher ER \& Greenstein RM. The von Hippel-Lindau (VHL) germline mutation V84L manifests as early-onset bilateral pheochromocytoma. American Journal of Medical Genetics, Part A 2006140 685-690. (https://doi.org/10.1002/ajmg.a.31116)

60 Allen RC, Webster AR, Sui R, Brown J, Taylor CM \& Stone EM. Molecular characterization and ophthalmic investigation of a large family with type 2A von Hippel-Lindau disease. Archives of Ophthalmology 2001119 1659-1665. (https://doi.org/10.1001/archopht.119.11.1659)

61 Atuk NO, Stolle C, Owen Jr JA, Carpenter JT \& Vance ML. Pheochromocytoma in von Hippel-Lindau disease: clinical presentation and mutation analysis in a large, multigenerational kindred. Journal of Clinical Endocrinology and Metabolism 199883 117-120. (https://doi.org/10.1210/jcem.83.1.4479)

62 Bender BU, Eng C, Olschewski M, Berger DP, Laubenberger J, Altehofer C, Kirste G, Orszagh M, van Velthoven V, Miosczka H, et al. VHL c.505 T >C mutation confers a high age related penetrance but no increased overall mortality. Journal of Medical Genetics 200138 508-514. (https://doi.org/10.1136/jmg.38.8.508)

63 Chen F, Slife L, Kishida T, Mulvihill J, Tisherman SE \& Zbar B. Genotype-phenotype correlation in von Hippel-Lindau disease: identification of a mutation associated with VHL type 2A. Journal of Medical Genetics 199633 716-717. (https://doi.org/10.1136/ jmg.33.8.716)

64 Crossey PA, Richards FM, Foster K, Green JS, Prowse A, Latif F, Lerman MI, Zbar B, Affara NA, Ferguson-Smith MA et al. Identification of intragenic mutations in the von Hippel-Lindau disease tumour suppressor gene and correlation with disease phenotype. Human Molecular Genetics 1994 3 1303-1308. (https://doi.org/10.1093/hmg/3.8.1303)
65 Curley SA, Lott ST, Luca JW, Frazier ML \& Killary AM. Surgical decision-making affected by clinical and genetic screening of a novel kindred with von Hippel-Lindau disease and pancreatic islet cell tumors. Annals of Surgery 1998227 229-235. (https://doi. org/10.1097/00000658-199802000-00012)

66 Glavac D, Neumann HP, Wittke C, Jaenig H, Masek O, Streicher T, Pausch F, Engelhardt D, Plate KH, Hofler H, et al. Mutations in the VHL tumor suppressor gene and associated lesions in families with von Hippel-Lindau disease from central Europe. Human Genetics 199698 271-280. (https://doi.org/10.1007/s004390050206)

67 Jalbani IK, Nazim SM \& Abbas F. Pheochromocytoma associated with von Hippel-Lindau disease in a Pakistani family. Urology Annals 20157 120-123. (https://doi.org/10.4103/0974-7796.148660)

68 Karsdorp N, Elderson A, Wittebol-Post D, Hene RJ, Vos J, Feldberg MA, van Gils AP, Jansen-Schillhorn van Veen JM, Vroom TM \& Hoppener JW. Von Hippel-Lindau disease: new strategies in early detection and treatment. American Journal of Medicine 199497 158-168. (https://doi.org/10.1016/0002-9343(94)90026-4)

69 Levine E, Collins DL, Horton WA \& Schimke RN. CT screening of the abdomen in von Hippel-Lindau disease. American Journal of Roentgenology 1982139 505-510. (https://doi.org/10.2214/ ajr.139.3.505)

70 Nielsen SM, Rubinstein WS, Thull DL, Armstrong MJ, Feingold E, Stang MT, Gnarra JR \& Carty SE. Genotype-phenotype correlations of pheochromocytoma in two large von Hippel-Lindau (VHL) type 2A kindreds with different missense mutations. American Journal of Medical Genetics, Part A 2011 155A 168-173. (https://doi.org/10.1002/ ajmg.a.33760)

71 Nielsen SM, Rubinstein WS, Thull DL, Armstrong MJ, Feingold E, Yip L, Tisherman SA \& Carty SE. Long-term outcomes, branch-specific expressivity, and disease-related mortality in von Hippel-Lindau type 2A. Familial Cancer 201110 701-707. (https://doi.org/10.1007/s10689011-9465-7)

72 Priesemann M, Davies KM, Perry LA, Drake WM, Chew SL, Monson JP, Savage MO \& Johnston LB. Benefits of screening in von Hippel-Lindau disease - comparison of morbidity associated with initial tumours in affected parents and children. Hormone Research 200666 1-5. (https:// doi.org/10.1159/000093008)

73 Pulcrano M, Camera L, Pagano L, Del Vecchio S, Ferone D, Bodei L, Murgia A, Pace L, Storto G, Paganelli G, et al. Usefulness of [111In-DTPA0] octreotide scintigraphy in a family with von HippelLindau disease. Journal of Endocrinological Investigation 200831 352-359. (https://doi.org/10.1007/BF03346370)

74 Qi XP, Liu WT, Li JY, Dai Y, Ma JM, Zhao Y, Fei J, Li F, Shen M, Jin HY, et al. P.N78S and p.R161Q germline mutations of the VHL gene are present in von Hippel-Lindau syndrome in two pedigrees. Molecular Medicine Reports 20138 799-805. (https://doi.org/10.3892/mmr.2013.1578)

75 Tong AL, Zeng ZP, Zhou YR, Yuan T, Cao CX, Zhang J \& Li M. Bilateral pheochromocytoma as first presentation of von Hippel-Lindau disease in a Chinese family. Chinese Medical Sciences Journal 200924 197-201. (https://doi.org/10.1016/s1001-9294(10)60001-6)

76 Weirich G, Klein B, Wohl T, Engelhardt D \& Brauch H. VHL2C phenotype in a German von Hippel-Lindau family with concurrent VHL germline mutations P81S and L188V. Journal of Clinical Endocrinology and Metabolism 200287 5241-5246. (https://doi. org/10.1210/jc.2002-020651)

77 Wu P, Zhang N, Wang X, Ning X, Li T, Bu D \& Gong K. Family history of von Hippel-Lindau disease was uncommon in Chinese patients: suggesting the higher frequency of de novo mutations in VHL gene in these patients. Journal of Human Genetics 201257 238-243. (https:// doi.org/10.1038/jhg.2012.10)

78 Yoshida M, Ashida S, Kondo K, Kobayashi K, Kanno H, Shinohara N, Shitara N, Kishida T, Kawakami S, Baba M, et al. Germ-line mutation analysis in patients with von Hippel-Lindau disease in Japan: an extended study of 77 families. Japanese Journal of Cancer Research 2000 91 204-212. (https://doi.org/10.1111/j.1349-7006.2000.tb00933.x) 
79 Huang YL, Zhou D, Liu JG, Zhou P, Li XD \& Wang Z. Germline mutations of the VHL gene in seven Chinese families with von HippelLindau disease. International Journal of Molecular Medicine 201229 47-52. (https://doi.org/10.3892/ijmm.2011.808)

80 Iida K, Okimura Y, Takahashi K, Inomata S, Iguchi G, Kaji H \& Chihara K. A variety of phenotype with R161Q germline mutation of the von Hippel-Lindau tumor suppressor gene in Japanese kindred. International Journal of Molecular Medicine 200413 401-404. (https:// doi.org/10.3892/ijmm.13.3.401)

81 Imanaka M, Iida K, Takahashi K, Tsuji K, Nishizawa H, Fukuoka H, Takeno R, Takahashi Y, Okimura Y, Kaji H, et al. The N131S mutation in the von Hippel-Lindau gene in a Japanese family with pheochromocytoma and hemangioblastomas. Endocrine Journal 2006 53 819-827. (https://doi.org/10.1507/endocrj.k06-046)

82 Liu P, Zhu F, Li M, Dube DA, Liu Q, Wang C, Xiao Q, Zhang L, Gao S, Li Z, et al. Von Hippel-Lindau 'Black Forest' mutation inherited in a large Chinese family. Gland Surgery 20198 343-353. (https://doi. org/10.21037/gs.2019.08.03)

83 André T, Bossard C, Gattegno B, Plouin PF, Benoit G \& Richard S. A type $2 \mathrm{~B}$ von Hippel-Lindau family masquerading as a metastatic sporadic renal cell carcinoma. BJU International 200391 425-426. (https://doi.org/10.1046/j.1464-410x.2003.04064.x)

84 Hull MT, Warfel KA, Muller J \& Higgins JT. Familial islet cell tumors in von Hippel-Lindau's disease. Cancer 197944 1523-1526. (https://doi.org/10.1002/1097-0142(197910)44:4<1523::aidcncr2820440452>3.0.co;2-0)

85 Sexton A, Rawlings L, McKavanagh G, Simons K \& Winship I. A novel von Hippel Lindau gene intronic variant and its reclassification from VUS to pathogenic: the impact on a large family. Journal of Genetic Counseling 201524 882-889. (https://doi.org/10.1007/s10897-0159875-z)

86 Zhang J, Wu D, Ai H, Bai J, Dong S, Yang Q, Qu K, Zhou L, Xu X \& Liu C. Epidemiological study of a von Hippel-Lindau family in northwest China. Frontiers of Medicine 20137 378-385. (https://doi. org/10.1007/s11684-013-0276-0)

87 Zhang B, Qian J, Chang DH, Wang YM, Zhou DH \& Qiao GM. VHL gene mutation analysis of a Chinese family with non-syndromic pheochromocytomas and patients with apparently sporadic pheochromocytoma. Asian Pacific Journal of Cancer Prevention 201516 1977-1980. (https://doi.org/10.7314/apjcp.2015.16.5.1977)

88 Arıcan P, Tekin BO, Naldöken S, Sefizade R \& Berker D. A family with von Hippel-Lindau syndrome: the findings of indium-111 somatostatin receptor scintigraphy, iodine-123 metaiodobenzylguanidine scintigraphy and single photon emission computerized tomography. Molecular Imaging and Radionuclide Therapy 201726 38-42. (https://doi.org/10.4274/mirt.70894)

89 Bleggi-Torres LF, De Noranha L, Fillus Neto J, Telles JE \& Madalozzo LE. Von Hippel-Lindau's disease: report of three cases and review of the literature. Arquivos de Neuro-Psiquiatria 199553 782-788. (https://doi. org/10.1590/s0004-282x1995000500012)

90 Cruz JB, Fernandes LPS, Clara SA, Conde SJ, Perone D, Kopp P \& Nogueira CR. Molecular analysis of the von Hippel-Lindau (VHL) gene in a family with non-syndromic pheochromocytoma: the importance of genetic testing. Arquivos Brasileiros de Endocrinologia e Metabologia 200751 1463-1467. (https://doi.org/10.1590/s000427302007000900008)

91 Cuatrecasas G, Oriola J, Granada ML, Florensa R \& Salinas I. Genetic screening in a new family with the type IIB von Hippel-Lindau disease. Medicina Clinica 1999112 546-548.

92 Palmar I, Vircburger M, Manojlovic D, Radevic B, Andjelkovic Z, Buric B, Savicevic M \& Neskovic G. The von Hippel-Lindau syndrome with pheochromocytoma. Srpski Arhiv za Celokupno Lekarstvo 2002130 (Supplement 2) 43-46.

93 Mete T, Berker D, Yilmaz E, Ozgen G, Yalcin Y, Tuna M, Ciliz D, Onen M, Aydin Y \& Guler S. Clinical presentation of von Hippel Lindau syndrome type 2B associated with VHL p.A149S mutation in a large Turkish family. Endocrine 201445 128-135. (https://doi. org/10.1007/s12020-013-9982-2)

94 Buffet A, Calsina B, Flores S, Giraud S, Lenglet M, Romanet P, Deflorenne E, Aller J, Bourdeau I, Bressac-de Paillerets B, et al. Germline mutations in the new E1' cryptic exon of the VHL gene in patients with tumours of von Hippel-Lindau disease spectrum or with paraganglioma. Journal of Medical Genetics 202057 752-759. (https:// doi.org/10.1136/jmedgenet-2019-106519)

Received in final form 14 September 2021

Accepted 30 September 2021

Accepted Manuscript published online 1 October 2021 https://ec.bioscientifica.com https://doi.org/10.1530/EC-21-0294
(C) 2021 The authors Published by Bioscientifica Ltd
This work is licensed under a Creative Commons Attribution-NonCommercial-NoDerivatives 4.0 International License.ifica com at $04 / 26 / 2023$ 10:18:13AM 